\title{
Economic Activity Slows In The Central Mississippi Valley In 1967
}

OST MEASURES of economic activity in the Central Mississippi Valley continued to advance during 1967, but at slower rates than in most other recent years. ${ }^{1}$ Growth in employment and population slowed considerably, while personal income advanced at a somewhat faster pace than in the preceding eight years. Construction contract awards rose substantially from late 1966 to late 1967.

Economic activity in the metropolitan areas of the Central Mississippi Valley showed the same general trend as in the region as a whole. Employment continued to rise in most metropolitan areas but at slower rates than in the previous eight years. Spending was about unchanged during the first half of 1967 but rose rapidly after mid-year. Construction contracts were up significantly in all metropolitan areas. Bank deposits and bank investments rose at an accelerated pace, while bank loan growth slowed.

In this article, combined data for Arkansas, Kentucky, Mississippi, Missouri, and Tennessee are analyzed to give a general picture of the region's growth. Thereafter, each state and metropolitan area is discussed separately. The primary period considered is from late 1966 (average September-November) to late 1967 (average September-October for states and September-November for metropolitan areas). ${ }^{2}$ The

\footnotetext{
1 For an analysis of national economic conditions during 1967 see "Economic Pause, Acceleration and Excesses-m 1967 in Retrospect" by Norman N. Bowsher in the December 1967 issue of this Review.

${ }^{2}$ Exceptons are population and per capita income figures, computed as of July I; total personal income figures for states, cumulative from January to September; and department store sales for metropolitan areas, cumulative from January to October. In each case comparisons are made with the same period a year earlier. Hours and earnings figures for metropolitan areas do not include data for November 1967 .
}

growth trend from the 1957-59 average to 1966 is used to place recent developments in perspective.

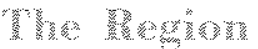

Total employment in the Central Mississippi Valley declined slightly from late 1966 to late 1967, reflecting both a continued downtrend in agricultural employment and a relatively slow gain in payroll employment. From the base period 1957-59 to 1966, employment in the region grew at about the same rate as in the nation. During 1967 the slowdown was more pronounced in the region than nationally.

Unemployment in the region rose during the first half of the year and then changed little subsequently. Regional unemployment increased from 3.7 per cent of the labor force in late 1966 to 4.2 per cent in late 1967. The national unemployment rates were the same as in the region in these periods.

Payroll employment was about unchanged on balance, as gains in nonmanufacturing approximately offset losses in manufacturing. Industries showing sizable declines included lumber and wood products and furniture and fixtures. About one-half of the 1.6 per cent reduction in manufacturing employment last year can be attributed to labor disputes. (Workers involved in strikes are not counted as either employed or unemployed.) Manufacturing employment has grown at a relatively high rate in the region during recent years. Manufacturing employment in the region rose 33 per cent from $1957-59$ to 1966 , whereas nationally such employment rose about 16 per cent.

Average hourly earnings of production workers in manufacturing in the Central Mississippi Valley in 1967 advanced faster than in the nation. Gains were particularly large in Mississippi, Arkansas, and Tennessee, where wages have traditionally been low. 
In analyzing the state and area data from late 1966 to late 1967, a more meaningful picture can be obtained by placing the nation's economy in its appropriate cyclical setting. Economic activity nationally was in a period of pronounced hesitation in late 1966 and early 1967. By early summer of 1967, however, the pace of economic activity had quickened, and the faster pace continued through the fourth quarter. Highly cyclical measures such as contracts awarded, which were in a trough in late 1966 , thus tend to overstate long-run growth possibilities. On the other hand, part of the employment slowdown in late 1967 was the result of an increase in striking workers that occurred with the business expansion.

Much of the change in banking activity in the region reflected a combination of monetary actions and cyclical forces. In late 1966 demand for loans was intense, while the supply of funds available to lend was restricted by the slower rate of growth of bank credit and money. By the second half of 1967 , however, monetary policy was very expansive, and demand for investment funds rose faster than demand for loans; thus the proportion of bank portfolios in investments rose.

Other data may not be precisely comparable. For example, total employment and total payroll em. ployment data are obtained from different samples. Similarly, the unemployment data for states and metropolitan areas are obtained from different series than the national unemployment figures. State population data are available only as of July 1 ; thus income per capita is calculated from July to July, while total personal income is based on year-to-date figures.

Despite these deficiencies, the data have been included to provide a complete set of indicators. For each state and metropolitan area, however, the set should be considered as a whole rather than separately in drawing conclusions relative to economic activity and growth.

Average earnings for the region advanced 5.7 per cent compared with a 3.6 per cent gain for the nation. Over the longer run, earnings in both the region and nation advanced at a 3.1 per cent rate. Average hours worked per week declined slightly in 1967 in all regional states.

Construction contracts in the region rose 17 per cent from late 1966 to late 1967. In the three-month period August-October, residential contracts exceeded by 50 per cent those of the corresponding months a year earlier, when the industry was unusually depressed. Conversely, nonresidential contracts declined somewhat over the same period.

Personal income in the Valley rose somewhat faster last year than in the longer period 1957-59 to 1966. Personal income figures are not adjusted for price changes, and 1967 was a year of rapidly rising prices. Thus, the growth in real income (money income ad justed for price changes) was probably about the same or less than the average of the previous years. In current dollars per capita personal income averaged $\$ 2,453$ in 1967 , an increase of 6.3 per cent from 1966 . From $1957-59$ to 1966 personal income in the region grew at the average rate of 6.2 per cent.

Population growth was slower in both the region and in the nation in the year ending in mid-1967 than in the previous eight years. Population in the five states combined advanced an estimated 0.6 per cent from 1966 to 1967 , compared with the trend rate of 1.2 per cent from 1957-59 to 1966 . Nationally, population rose 1.0 per cent last year and at a 1.5 per cent rate during the longer period from 1957-59 to 1966.

\section{A.}

The Arkansas economy paused during 1967, after expanding very rapidly from 1957-59 to 1966. Total employment dipped slightly at mid-year but had regained the previous peak by late 1967 . The unemployment rate rose to 4.7 per cent, the highest level in the state since mid-1965. On the other hand, average hourly earnings of manufacturing workers increased substantially. Despite the hesitation in 1967, most measures of economic activity in Arkansas increased faster than in the nation over the longer period from $1957-59$ to 1966 .

Payroll employment, which accounts for about threefourths of total employment, rose 1.0 per cent during the year, with a gain in nommanufacturing more than offsetting a slight decline in the manufacturing sector. The construction and service categories showed significant increases in employment, while lumber and wood product and apparel industries in the manufacturing sector had sizable declines.

Average hotrly earmings of production workers in manufacturing during 1967 rose 7 per cent, about double the national increase and also double the rate of increase in Arkansas from 1957-59 to 1966. At \$2.04, however, average hourly earnings in Arkansas last year were still well below the $\$ 2.85$ average for the United States. During the year average weekly hours worked declined from 41.5 to 40.9 , about the same decrease as in the nation. The unemployment rate in September-October of 4.7 per cent was slightly higher than a year eartier, but has declined since mid-year.

Construction contracts awarded rose 14 per cent from late 1966 to late 1967. Residential contracts rose 


\section{Arkansas}
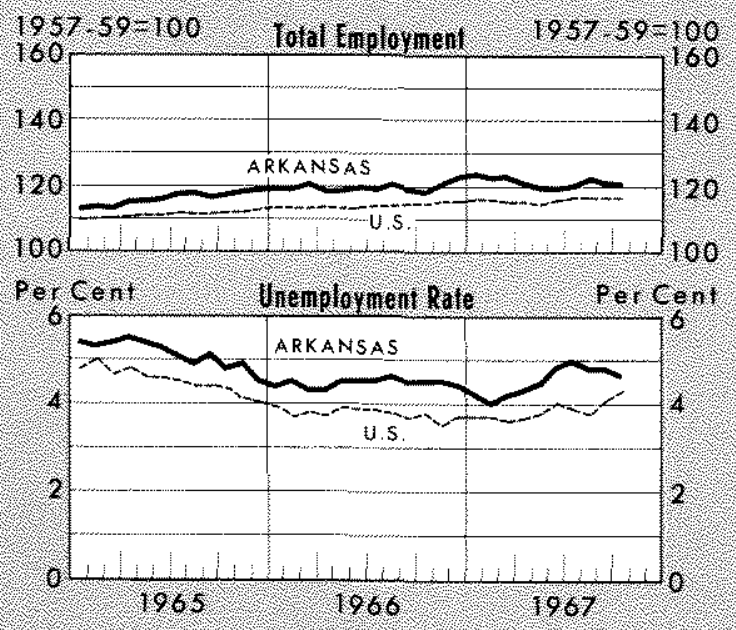

Income

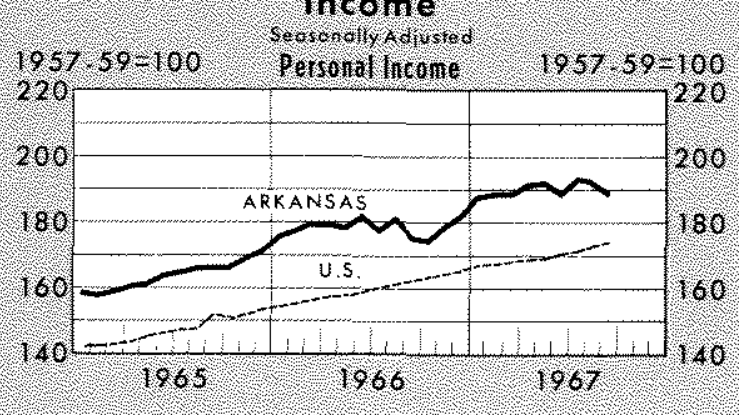

sharply, while nonresidential contracts declined somewhat, in accordance with regional trends. Employment in the construction industry rose by 2,300 , a gain of 6 per cent.

Personal income rose 6 per cent in 1967, compared with a 7 per cent average rate of gain in the last eight years. Although gains in income have been large in the state, per capita income, estimated at $\$ 2,123$ in 1967, was still below both the regional and national averages.

Population expanded 0.7 per cent in 1967, about half the rate of the preceding eight years. In mid-1967 the population of Arkansas was estimated at $1,969,000$.

\section{Little Rock}

Economic activity in the Little Rock Metropolitan Area continued to expand last year, but at a reduced rate. Employment rose slightly, and unemployment also moved up from late 1966. At 2.7 per cent of the labor force, the unemployment rate in late 1967 was still very low relative to regional and national rates.
Payroll employment showed a net gain for the year of 1.6 per cent. It rose sharply in late 1966 and early 1967, declined somewhat during the late winter and spring, but turned upward again at mid-year. Manufacturing employment declined during the fall of 1967 but late in the year was still 2.5 per cent above the level of the previous year. Employment in the metals industries increased by several hundred, while employ.

\section{Little Rock Metropolitan Area}
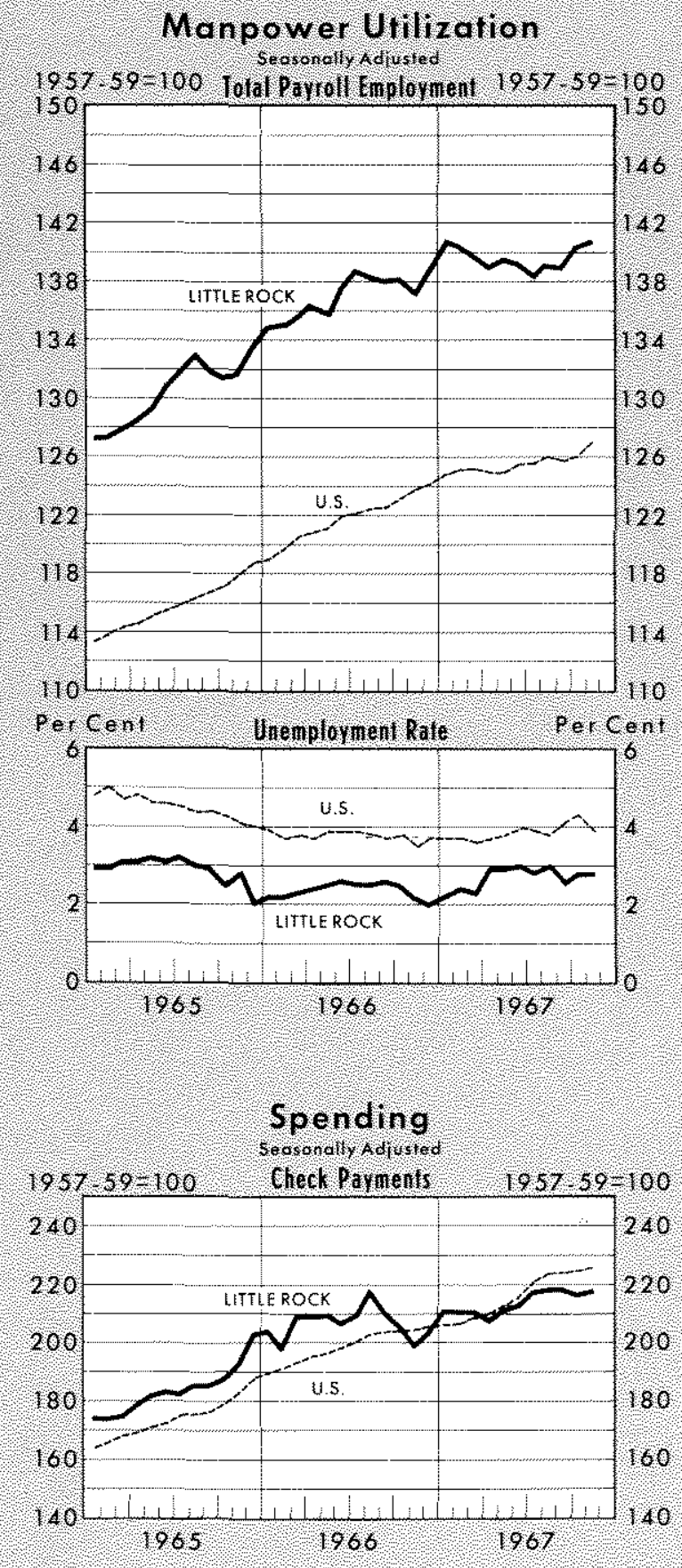
ment in lumber and wood products and furniture and fixtures declined. Nonmanufacturing employment rose slightly, with the largest gain in state and local government.

Construction contracts for Little Rock in late 1967 were well above year-earlier levels. Construction contracts rose 46 per cent, with contracts for residential purposes showing a much larger increase than for nonresidential. These gains have been partially reflected in construction activity, as employment in the construction industry rose slightly.

Check payments, a measure of over-all spending, rose 6 per cent during the year, with most of the gain in the second quarter, after expanding at a 10 per cent annual rate from 1957-59 to 1966. Department store sales rose 8 per cent last year, about average for the other large metropolitan areas in the region.

Bank deposits increased rapidly and loan growth slackened, reflecting the very expansive national monetary policy and slower growth in demand for loans. Bank investments rose 9 per cent during the year, after remaining relatively unchanged during the $1957-59$ to 1966 period.

\section{Fort Smith}

The Fort Smith economy, which had declined sharply in the second half of 1966 as a result of layoffs in one plant, rebounded last year. By mid-year, employment had about regained the early 1966 level, and unemployment had declined. Construction contracts were substantially greater in the period August-October 1967 than in the corresponding months a year earlier.

The unemployment rate in Fort Smith declined to 5.2 per cent of the labor force in late 1967 from 7.4 per cent a year earlier. While the 1967 rate was above that of other regional metropolitan areas and the nation, it was less than the average rate for Fort Smith during other recent years.

Payroll employment rose 4.7 per cent in 1967 , with most of the gain occurring before mid-year. Manufacturing employment declined sharply in late 1966, when a large electrical machinery manufacturing firm reduced employment following a change of ownership. However, it regained the earlier level in 1967. Construction, which had been in a slump following the closing of Fort Chaffee in 1965, also showed a sizable employment gain. Construction contracts rose 17 per cent from the year-earlier level, with all of the gain in residential awards.

Spending in Fort Smith grew slowly last year. Check payments increased 6 per cent, somewhat below the

\section{Fort Smith Metropolitan Area}
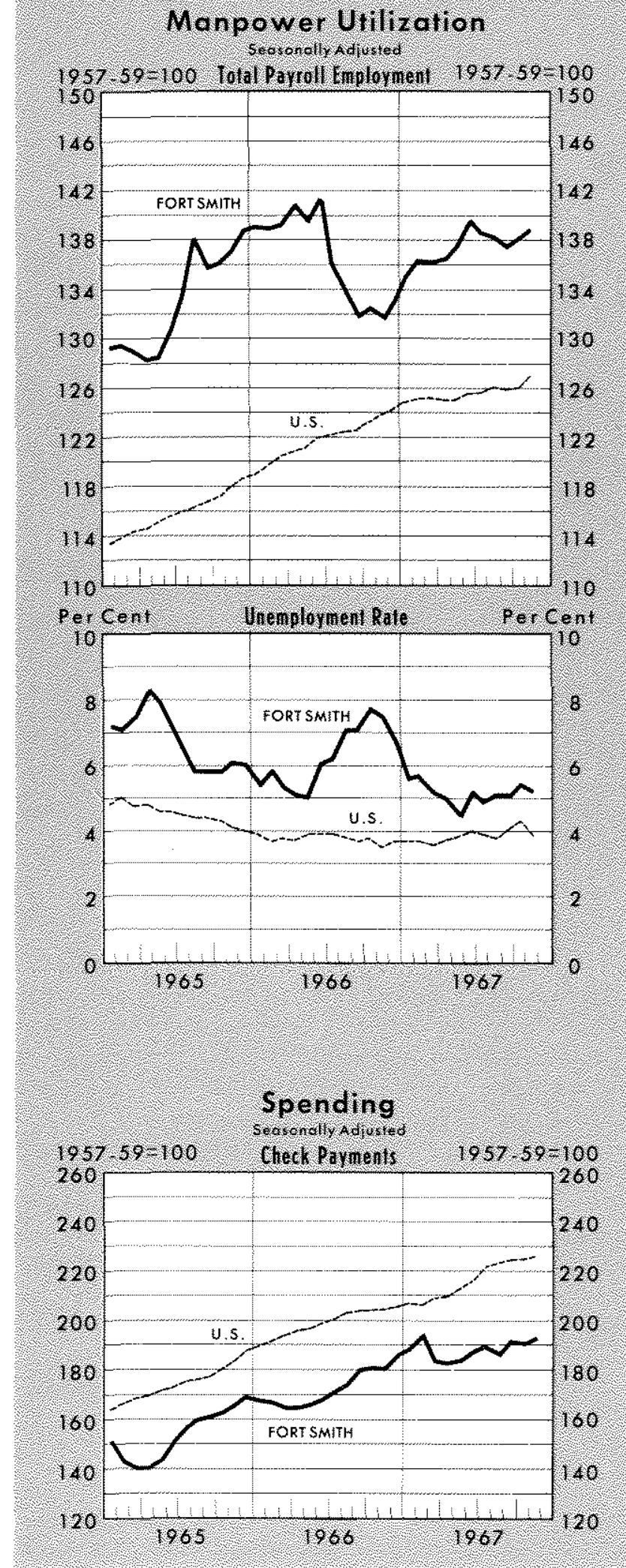
longer-term rate. Department store sales in the Fort Smith area advanced 1.0 per cent.

Banking activity grew more slowly in Fort Smith than in other regional metropolitan areas. Deposits rose 7 per cent, with most of the gain after mid-year. Total loans were essentially unchanged. Bank investments rose very rapidly, corresponding to the trend in other metropolitan areas and the nation.

\section{Pine Bluff}

Following several years of rapid expansion, economic activity in Pine Bluff slowed in 1966 and had not regained its previous momentum by late 1967 . Employment has been about unchanged during the past two years. Unemployment increased moderately during the year ending in late 1967, rising from 3.7 to 4.1 per cent of the labor force.

The stability of payroll employment in 1967 resulted from an increase of about 3 per cent in non-manufacturing employment, which was offset by a decline in manufacturing employment. Agricultural employment in the area, which includes all of Jefferson County, declined more than usual late in the year because of a smaller cotton crop.

Despite the employment slowdown, average hourly earnings of production workers in Pine Bluff manufacturing firms increased at a significant rate. Such earnings rose 12 per cent in the year to $\$ 2.54$ per hour in late 1967. This was well above the regional and national increases of 4.3 and 3.6 per cent, respectively.

Check payments expanded in early 1967 and declined in later months, partially as a result of reduced cotton marketings. Cotton production in the area served by the Pine Bluff market was well below the yearearlier crop. Deposits rose 8 per cent, equaling the trend rate, while loans rose 6 per cent, about half of the trend rate. Investments were up substantially in accordance with regional and national trends.

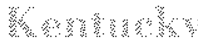

Economic activity in Kentucky remained about unchanged during 1967. Payroll employment and population changed little, and personal income rose at a slightly faster rate than in preceding years.

Total employment declined 2.3 per cent over the year, as the long-term decline in agricultural and other non-payroll employment was not offset by gains elsewhere. The unemployment rate of 4.1 per cent in late 1967 was slightly higher than a year earlier.

Payroll employment in Kentucky was about un-

\section{Pine Bluff Metropolitan Area}



changed in the year ending in late 1967. Manufacturing employment declined 3 per cent, reflecting in part a larger number of workers involved in labor disputes. The apparel and food products industries increased their employment substantially, while the electrical machinery industry showed a large decrease. Average weekly hours in manufacturing declined from 41.2 to 
40.6 , corresponding closely to the national pattern. Average hourly earnings rose 4.8 per cent to $\$ 2.73$. This compares with a growth rate of 3.1 per cent during the previous eight years. Nonmanufacturing employment rose 1.3 per cent, with growth primarily in trade, services, and government.

The sharp decline in construction employment which began in 1966 continued last year. In late 1967, 7,500 fewer construction workers were employed than a year earlier. Construction contracts, however, were up 10 per cent, with a sharp increase in residential more than offsetting a decline in nonresidential awards. These awards are an indicator of future construction activity. The marked increase in construction contracts from late 1966 to late 1967 thus indicates that construction employment may soon be on the upturn.

Personal income in Kentucky advanced 8 per cent in 1967, compared with an average annual growth rate of 6 per cent from 1957-59 to 1966. Per capita income of $\$ 2,416$ was about average for the Central Mississippi Valley, but well below the national average of $\$ 3,157$. The income gap between Kentucky and the nation as a whole has been narrowing percentagewise since 1957-59.

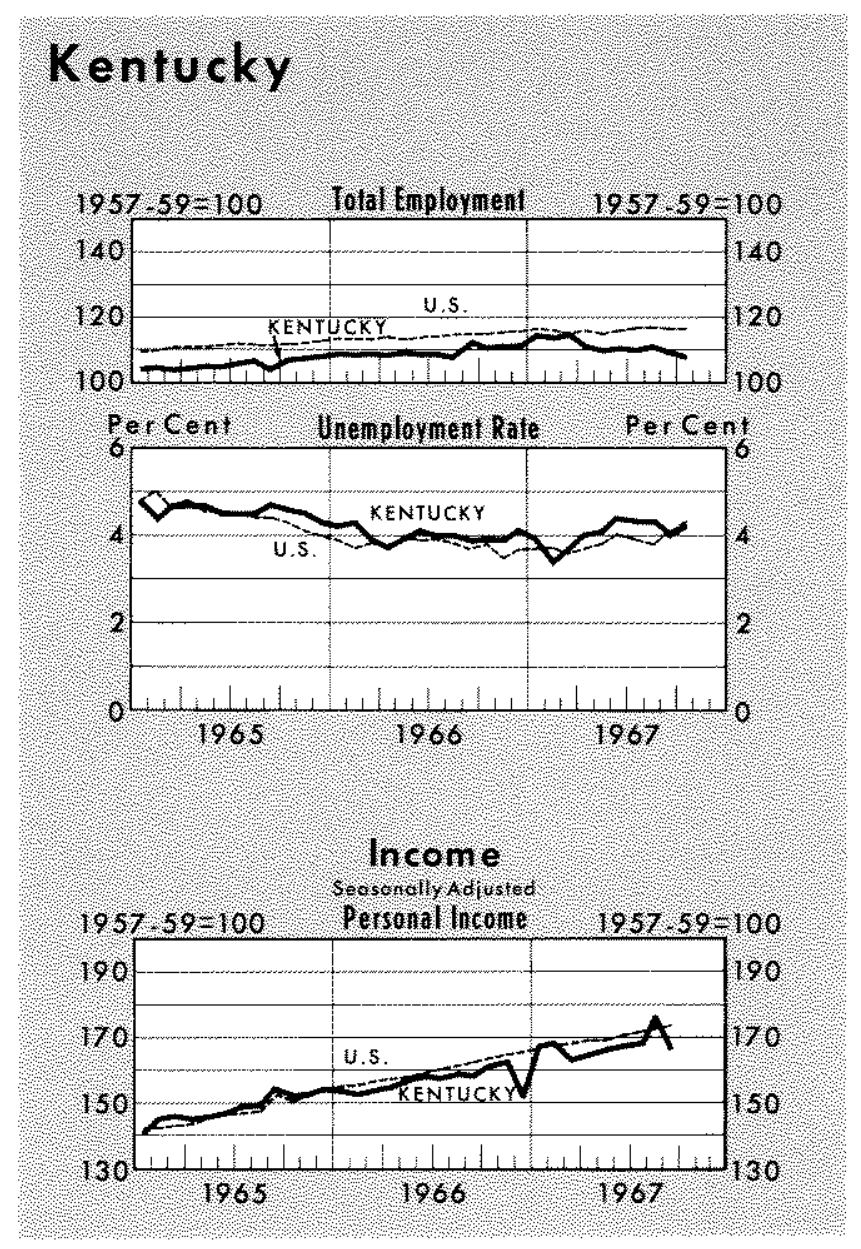

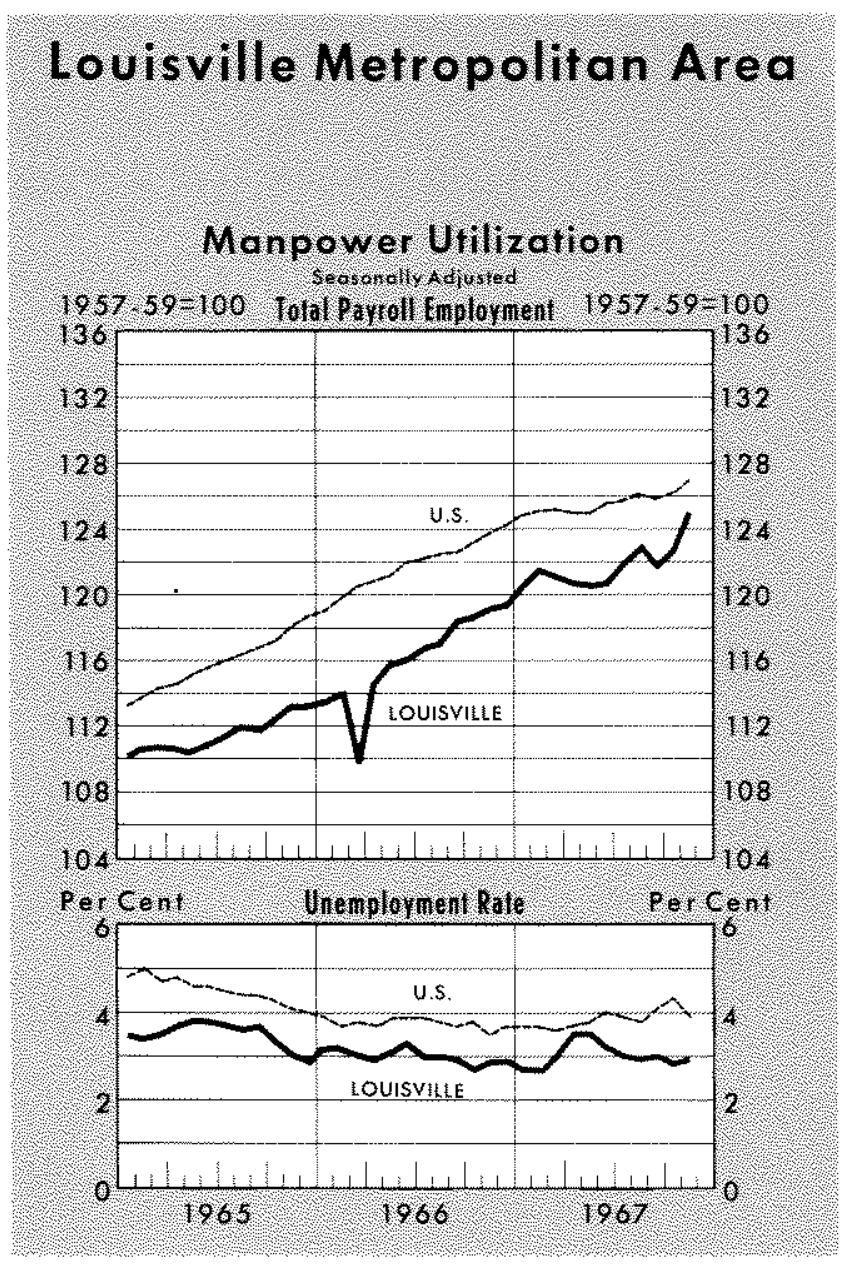

Population rose 0.3 per cent from mid-1966 to mid1967. This was about one-third the annual rate of increase for the state in the preceding eight years, and well below the 1.0 per cent increase in $\mathrm{U}$. S. population during 1967.

\section{Louisville}

Economic growth in Louisville was more rapid than in most other metropolitan areas of the region during 1967. Employment, construction, spending, and banking activity all advanced rapidly.

Total employment advanced 3.8 per cent during the year, and unemployment was a relatively low 2.9 per cent of the labor force in late 1967. Unemployment rose in the spring but subsequently declined to the late 1966 level.

Payroll employment rose 3.7 per cent in Louisville during 1967, with gains in both the manufacturing and nonmanufacturing sectors. Manufacturing employment increased 3.9 per cent, despite labor disputes late in the year involving 5,000 workers. Employment in ordnance more than doubled. Nonmanufacturing employment rose 3.5 per cent in 1967, with increases of 
more than 1,000 in each of the categories - trade, services, and government. Average hourly earnings in manufacturing rose 1.0 per cent, less than in the other metropolitan areas in the region. At $\$ 3.05$ the Louisville average earnings in manufacturing is second only to St. Louis among district metropolitan areas, and is above the national average.

Substantial increases in construction activity were evident in Louisville last year. Construction employment rose by 500 , an increase of 3 per cent. The value of construction contract awards rose 14 per cent.

Check payments at Louisville banks rose 4 per cent in 1967, somewhat less than the long-term trend from 1957-59 to 1966. Department store sales, however, rose a brisk 7 per cent, well above the national rate of gain.

Banking activity followed the same general trends as in most other regional metropolitan areas and in the nation. Deposit growth accelerated, loans advanced at a slower rate, and investments jumped 30 per cent.

\section{Evansville, Indiana-Kentucky}

Employment in the Evansville area declined slightly in 1967 , but spending and banking activity continued to rise.

Total employment declined 0.4 per cent, reflecting a drop in payroll employment. The unemployment rate turned upward in late 1966 and moved to above 4 per cent in the spring of last year. It subsequently declined to about 3.4 per cent, well below the preceding eight-year average.

Payroll employment in Evansville declined 1.2 per cent, following a very substantial gain in 1966. This

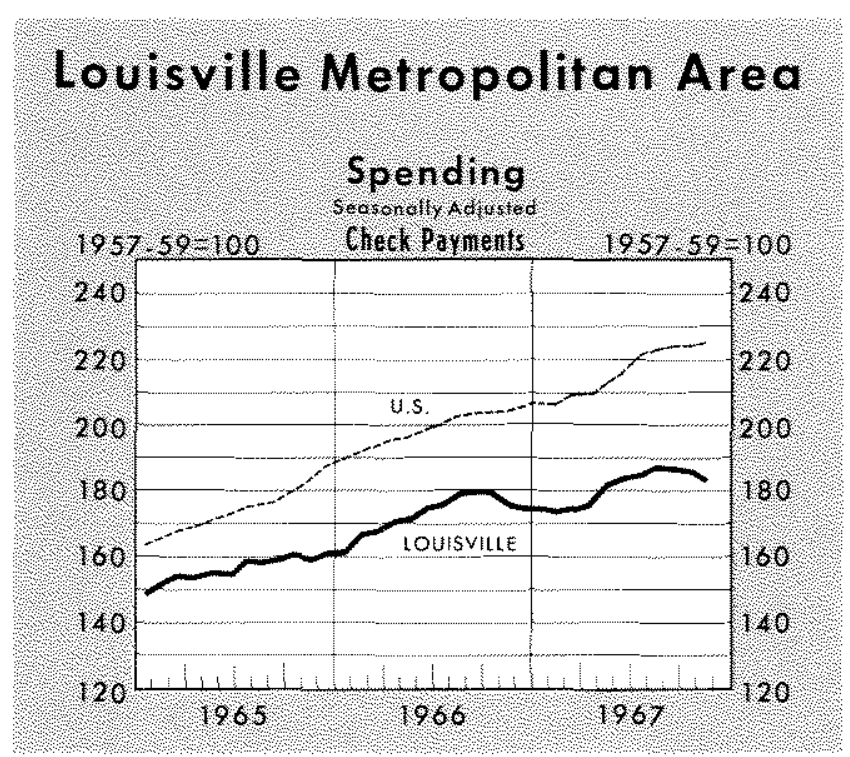

\section{Evansville Metropolitan Area}

Manpower Utilization

$80080001,+2014=0$

$1957.59=100$. 10lel Payroll Employinent $1957,59=100$
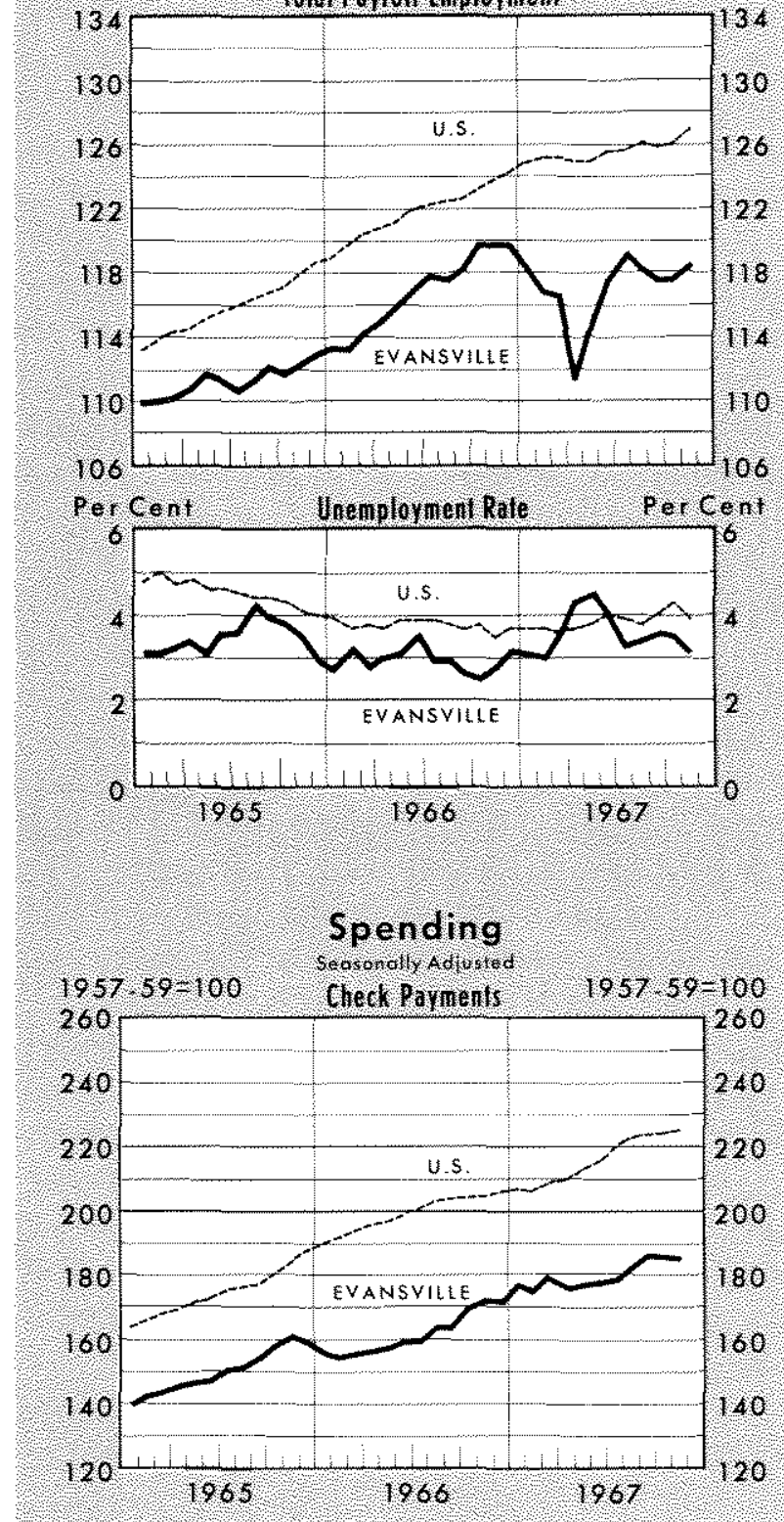

decline, all in the manufacturing sector, resulted from a major cutback in the refrigeration and airconditioning industry. Employment in this industry increased by 2,000 in 1966, but this gain was not sustained, as demand for products of this industry declined with the cutback in construction last year. Nonmanufacturing employment declined sharply in April due to a strike in the construction industry, but late in the year had more than recovered the loss.

Construction contracts awarded in late 1967 were 
2 per cent above a year earlier, with most of the gain in nonresidential awards. Construction employment was essentially unchanged.

Spending, as measured by check payments, rose 10 per cent in Evansville during 1967, well above the longer-term rate of 6 per cent.

Bank deposits and loans grew rapidly, reflecting a very expansive monetary policy. Deposits rose 13 per cent, substantially above the rate for the preceding eight years. Loans increased 10 per cent, also above the trend rate and well above the rate in most regional metropolitan areas last year. Bank investments also rose significantly.

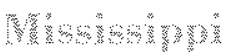

A considerable slowdown was evident in the Mis. sissippi economy last year after several years of rapid expansion.

Total employment declined 1.0 per cent during the year, reflecting a slower rate of growth in payroll employment and a sharp decline in agricultural workers. Agricultural employment was down about 7,000 . The unemployment rate, which had declined for several

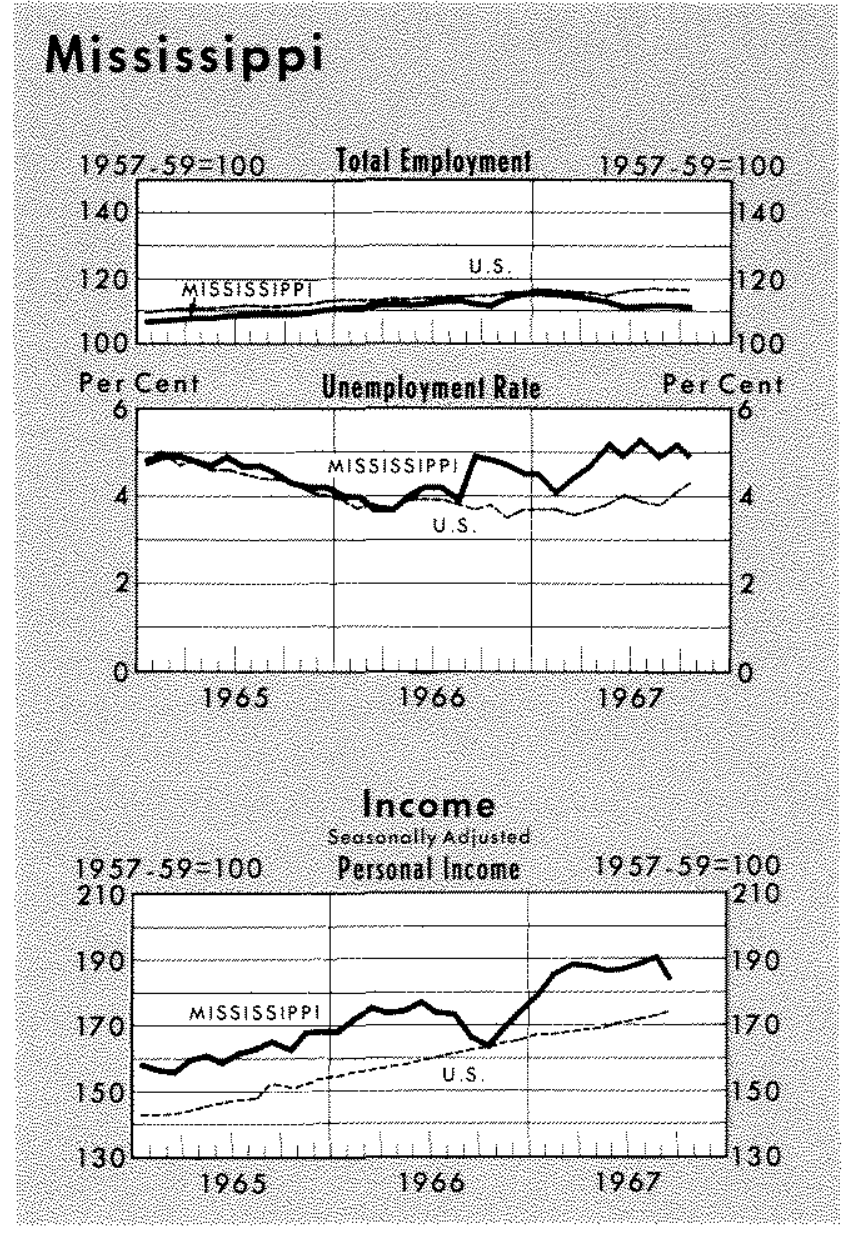

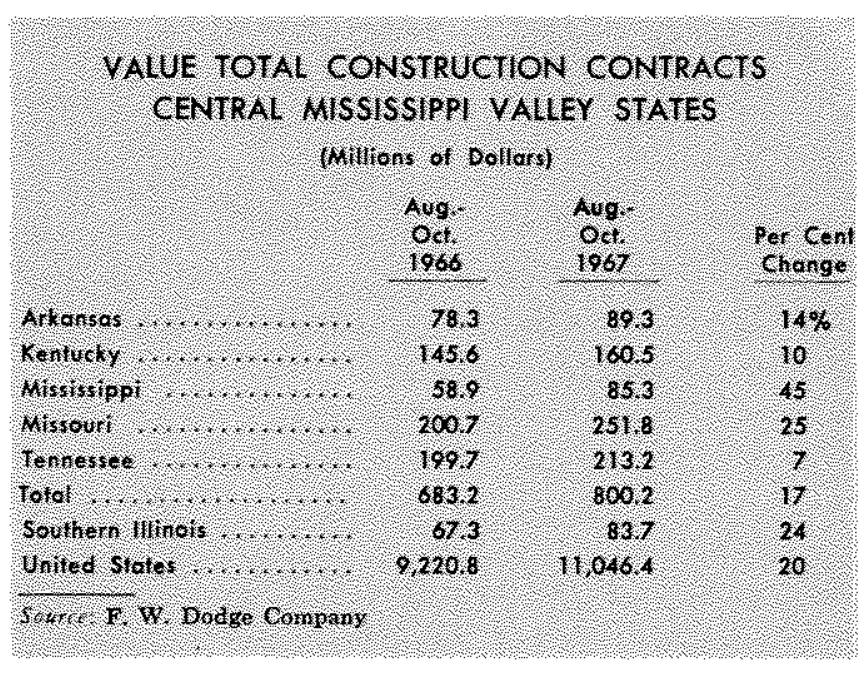

years, rose during the first half of 1967 and remained at about 5 per cent of the labor force during the autumn months.

Payroll employment was about unchanged last year, following fairly steady increases of about 4 per cent per year in the previous eight years. Manufacturing employment declined 2.1 per cent, reflecting both the general economic slowdown and labor disputes. As in Arkansas, the lumber and wood products and furniture industries reported the largest employment decreases. Average hourly earnings in manufacturing rose 8 per cent to $\$ 2.07$, but average hours worked per week declined slightly.

Nonmanufacturing employment in Mississippi increased slightly, as employment gains in wholesale and retail trade and local government more than offset a decline in construction employment. In late 1967 construction contracts were well above 1966 levels. Changes in construction activity should follow changes in contract awards. Thus, construction employment may soon be on the upturn in the state.

Personal income in Mississippi rose 6 per cent in 1967 with most of the gain in the first quarter. Per capita income, which had advanced at a faster rate than in the nation for several years, failed to equal the national growth rate in 1967 .

Population rose 0.5 per cent from mid-1966 to mid1967 , compared with a 1.3 per cent average rate in the longer-run period.

\section{Mestom}

Population and income expanded moderately in Missouri during 1967, but employment remained essentially unchanged.

The stable level of employment reflected a decline of 


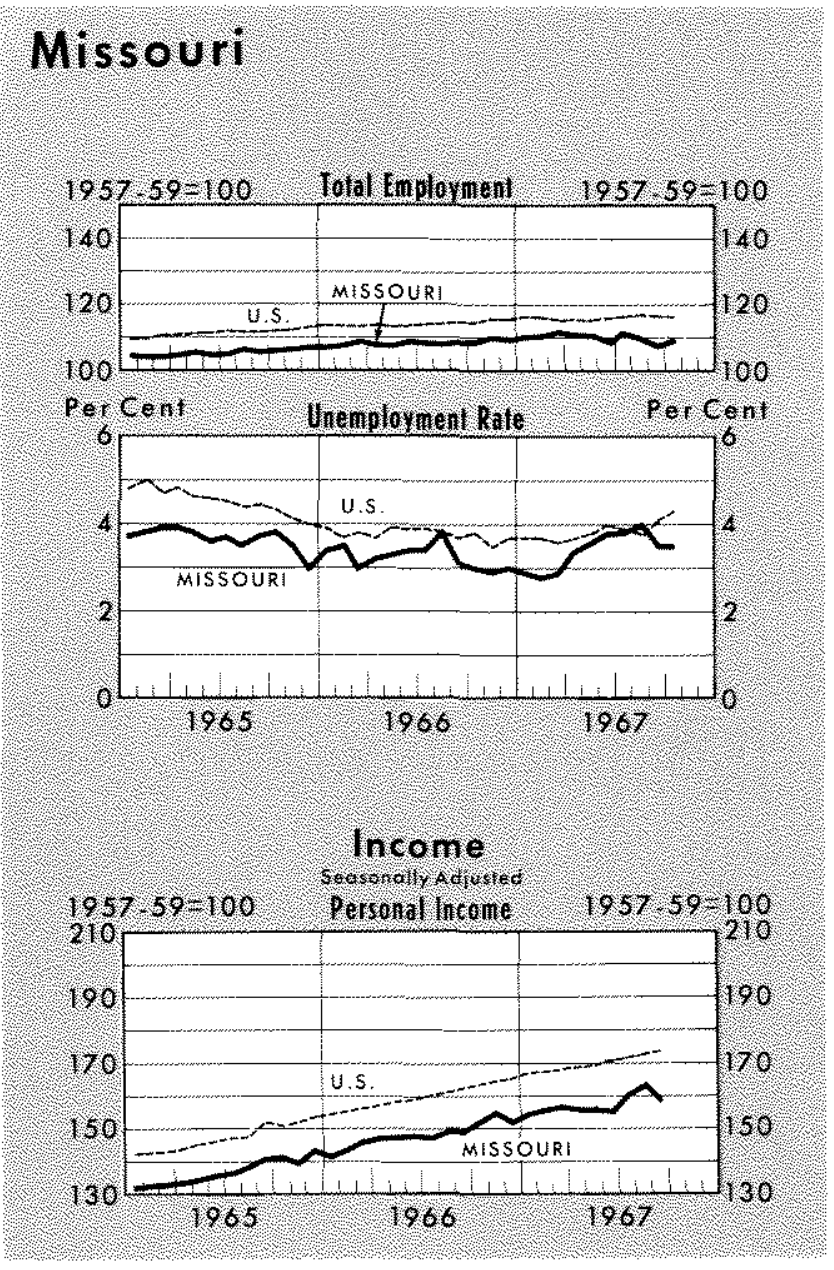

about 11,000 workers in agriculture, which was nearly offset by an increase in payroll employment. The unemployment rate rose from about 3.0 per cent in late 1966 to 3.9 per cent in the summer months, but declined later in the year.

Manufacturing employment in Missouri was about unchanged for the year ending in late 1967. Nonmanufacturing employment rose 2.3 per cent, reflecting sizable increases in service and state and local government employment. Employment in the construction industry decreased substantially. Construction contracts in late 1967, however, were well above yearearlier levels.

Personal income rose at a faster rate than in the nation or in Missouri in the previous eight years. Per capita income increased faster than the long-run rate. Per capita income, estimated at $\$ 3,000$, was higher than in any other Central Mississippi Valley state and only slightly below the national average.

\section{St. Louis}

Economic activity in the St. Louis Metropolitan Area advanced at a slower rate in 1967 than in most other recent years. A decline in automobile production early in the year, together with increased labor disputes, partially accounted for the slowdown. Increased defense activity was an offsetting factor.

Total employment was about unchanged over the year, compared with a 1.5 per cent average annual rate of gain in the previous eight years. Unemployment was 3.5 per cent of the labor force in late 1.967 ,

\section{St. Lovis Metropolitan Area}

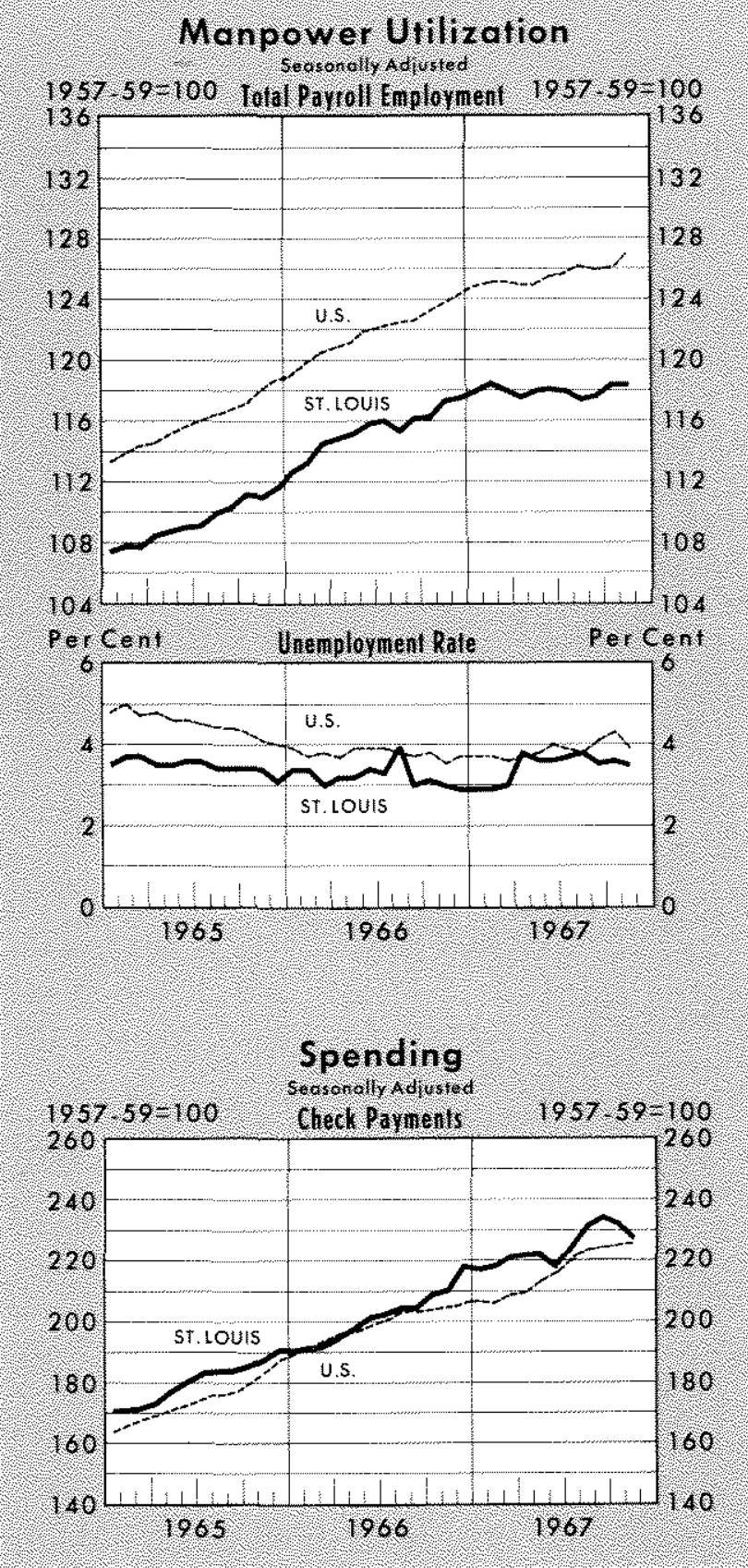


somewhat above the 1966 rate, but about average for the previous two years.

Payroll employment rose 1.5 per cent on balance, with an increase in nonmanufacturing employment more than offsetting a slight decline in the manufacturing sector. Employment in the trade, service, and government groups each rose by several thousand. In the manufacturing sector, defense industries (specifically ordnance, aircraft, and electrical machinery) showed sizable increases. On the other hand, employment in primary metals and motor vehicle manufacturing was substantially less than a year earlier, partially due to labor disputes. The gradual long-term decline in employment by producers of nondurable goods continued. Average hourly earnings in manufacturing rose 4.9 per cent to $\$ 3.22$, the highest in the region and well above the U.S. average.

Construction activity declined during 1967. Construction employment was substantially less in late 1967 than a year earlier. Recent trends in construction contracts awarded, however, point to increased activity in this area. During the three months August-October the value of such contracts was 43 per cent above yearearlier levels.

Spending in St. Louis, which slowed during the first six months, advanced rapidly after mid-year. Check payments rose 11 per cent, with most of the gain in the last half year. This was well above the eight-year trend rate of 9 per cent. Department store sales advanced 8 per cent.

Activity at St. Louis banks quickened, in line with national trends during the past year. Deposits increased 8 per cent and loans rose 5 per cent, compared with longer-term growth rates of 4 per cent for deposits and 7 per cent for loans. Bank investments, which had changed very little on balance from 1957-59 to 1966 , rose 19 per cent last year.

\section{Springfield}

In contrast to some leveling off of economic activity in most metropolitan areas of the region in 1967, activity continued to expand at a high rate in the Springfield area. Growth in spending, banking activity, and construction was very rapid. Employment continued to expand but at a slower rate.

Total employment rose 1.4 per cent. The unemployment rate advanced from 3.0 per cent early in the year to 4.0 per cent at mid-year and then declined somewhat. Late in the year the unemployment rate was well below the average of the preceding eight years.

Payroll employment in Springfield increased 2.9 per cent during 1967, with both manufacturing and nonmanufacturing sectors sharing in the gain. Most of the manufacturing employment increase was attributed to expansion by a manufacturer of color televisions, while small gains occurred in several nonmanufacturing categories. From 1957-59 to 1966 payroll employment rose at an average 3.0 per cent rate.

Construction employment in late 1967 was about unchanged from a year earlier, but the value of con-

\section{Springfield Metropolitan Area}

\section{Manpower Utilization}

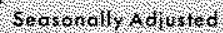

$1957.59-100$ 10bl Pavroll Employnent $1957.59=100$
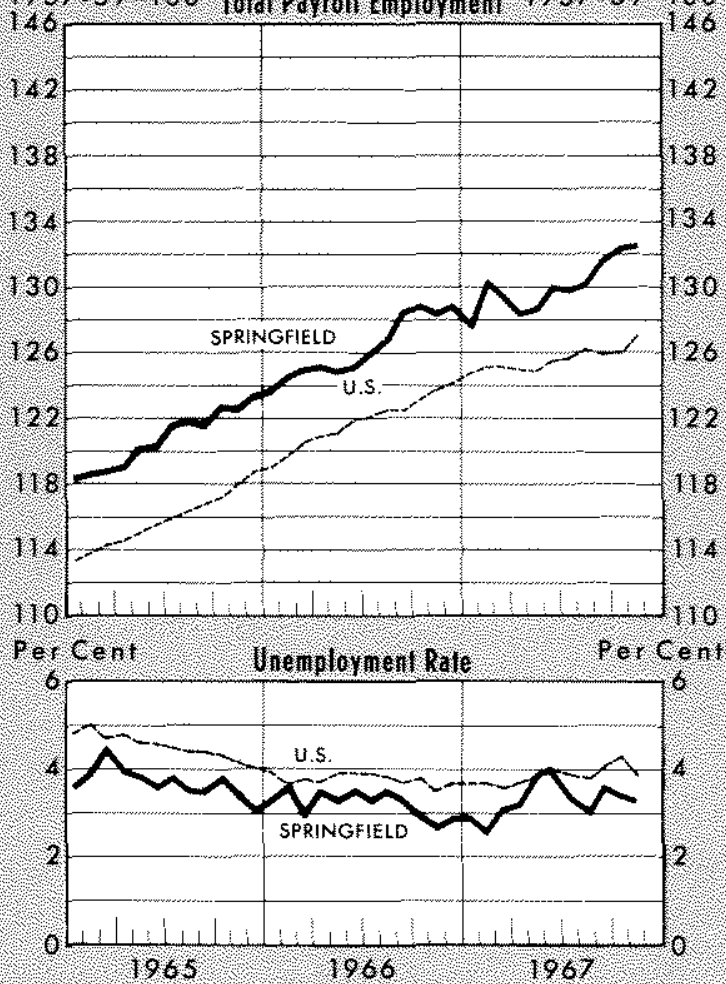

pending

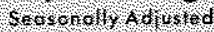

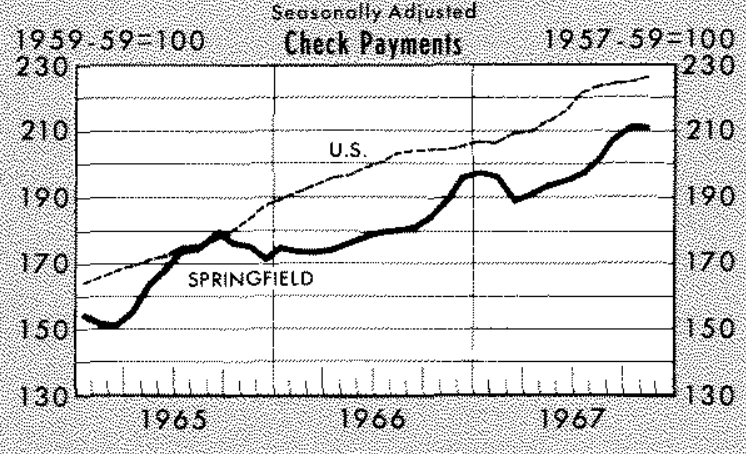


struction contracts awarded advanced sharply, particularly in the nonresidential sector. Total contracts awarded during August-October were up 60 per cent from the level during the same months a year earlier.

Check payments rose 14 per cent during 1967 compared with a trend rate of 8 per cent. Department store sales were 5 per cent above the level of late 1966 , about the same as the national rate of gain.

Deposits at Springfield banks rose 24 per cent and loans were up 20 per cent, but the increase in loans reflects in part net purchases of loans from banks in other areas. Bank investments also rose at a very rapid rate, continuing the trend since 1957-59.

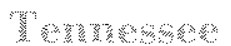

Economic trends in Tenmessee were typical of other Central Mississippi Valley states during 1967. Payroll employment was relatively stable. Personal income continued to advance moderately, and population increased at a slower rate than in most previous years.

From late 1966 to late 1967 total employment declined 2.1 per cent, and the unemployment rate rose from 3.4 per cent to 4.3 per cent. Prior to April 1967, the unemployment rate in Tennessee had been below the national average. Since April the rate has generally been above the national average.

Little growth occurred in payroll employment in Tennessee during 1967. This stability was the result of a decline of about 2 per cent in manufacturing $\mathrm{em}$ ployment and a small gain in nonmanufacturing. Greatest declines in the manufacturing sector occurred in the furniture industry and in stone, clay, and glass manufacturing. Manufacturing employment levels were also depressed in the autumn months by a larger-thanusual number of striking workers. A small increase in nonmanufacturing employment was largely the result

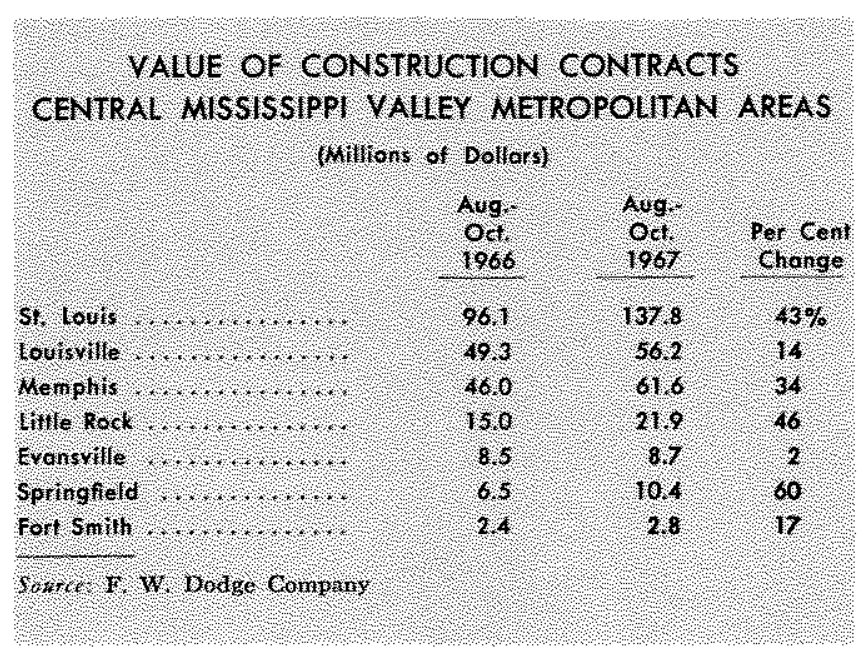

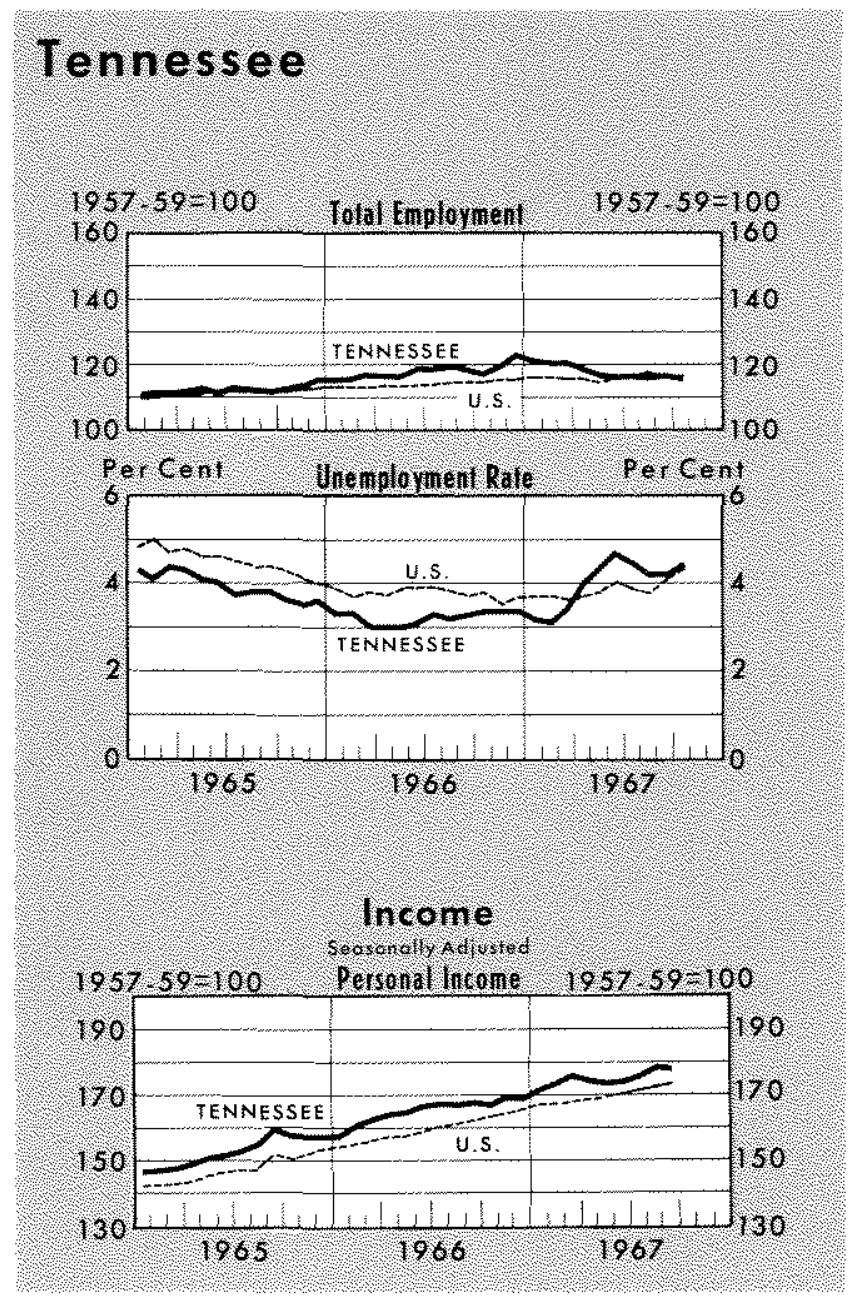

of growth in state and local government payrolls.

As in the other states with relatively low wages compared with the national average, hourly earnings of manufacturing workers in Tennessee increased substantially in 1967, and hours worked declined slightly. These wage gains relative to the national average indicate that the former reservoirs of surplus labor in the region are being depleted.

Construction contracts rose 7 per cent over levels of late 1966, with residential awards increasing substantially to more than offset a decline in nonresidential awards.

Personal income rose 7 per cent in 1967, about the trend rate for the previous eight years. Per capita income advanced 5.5 per cent to $\$ 2,349$. Although the rate of gain in per capita income in the state has been somewhat above the average for both the region and the nation, per capita income in the state is low relative to both.

Population in Tennessee in mid-1967 was estimated at $3,888,000$, a 0.6 per cent increase over 1966 . This 


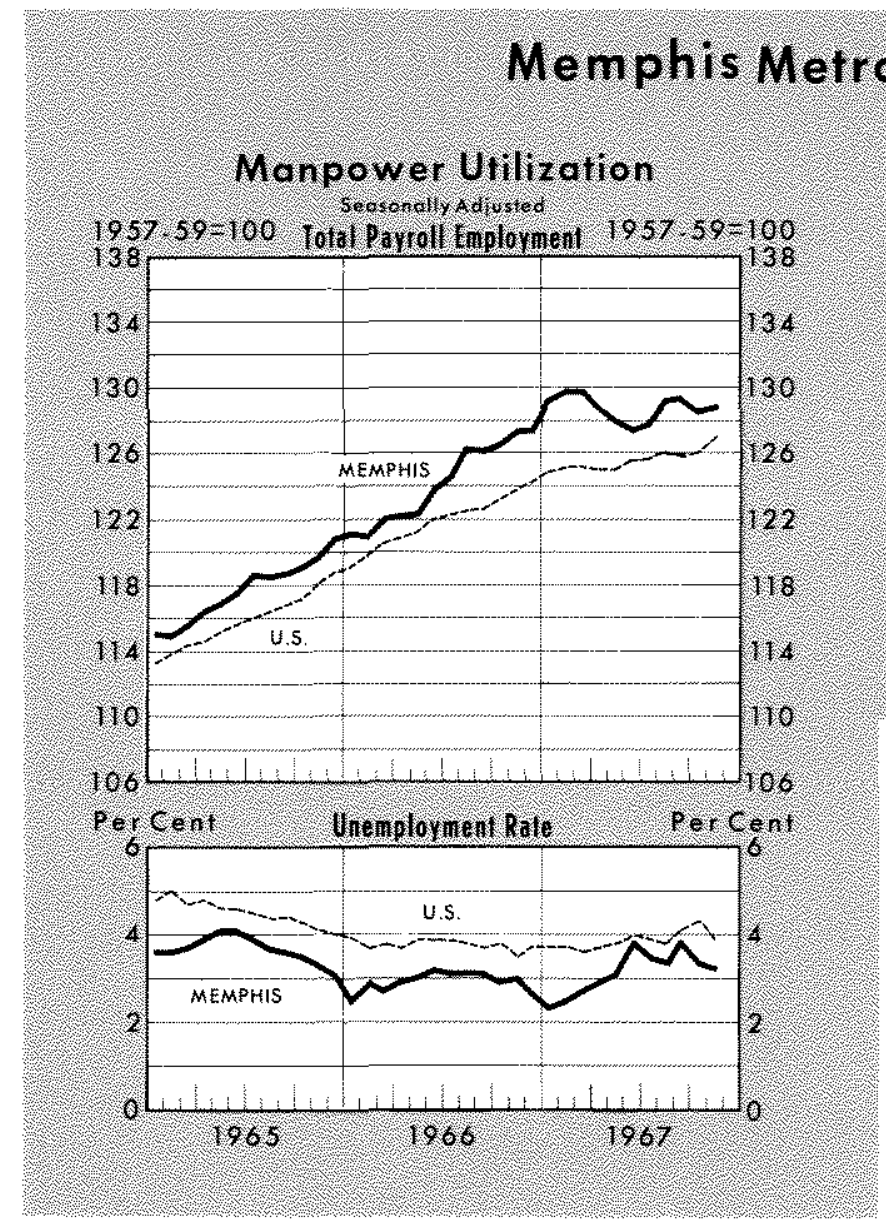

was less than half the growth rate of the 1957-59 to 1966 period.

\section{Memphis}

Economic activity in the Memphis area showed mixed trends in 1967, with banking activity, average hourly earnings, and department store sales expanding rapidly. Employment, however, gained little on balance.

The unemployment rate rose from 2.3 per cent early in the year to about 3.6 per cent at mid-year and then fluctuated near the higher level. Unemployment rates in late 1967 were still well below the national rates.

Total employment in Memphis was about unchanged from late 1966 to late 1967. Payroll employment rose 1.8 per cent, well below the trend rate of 2.7 per cent in the previous eight years, Manufacturing employment increased in the first quarter and then declined sharply in the spring and early summer as the result of a decline in the nonelectrical machinery industry and a strike of 2,400 workers in the rubber
Spending

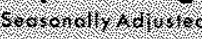
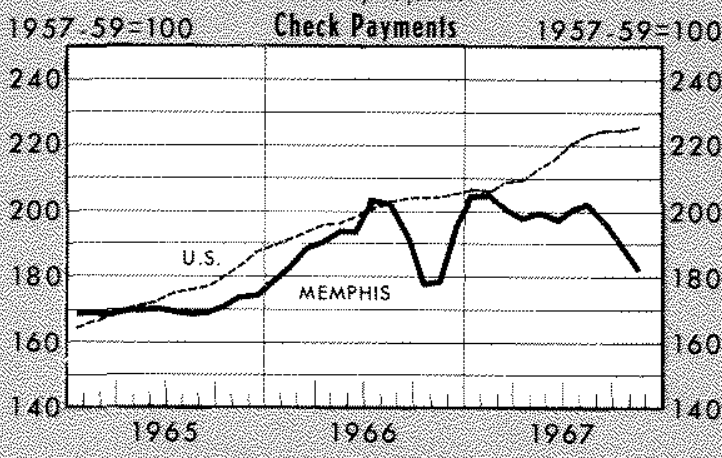

industry. Following settlement of the strike, manufacturing employment moved upward, but it had not regained the high February-March level by late 1967. The electrical machinery industry had the largest increase among manufacturing industries in the Memphis area. Nonmanufacturing employment has remained about unchanged since January, following an increase in late 1966.

Construction employment declined by several hundred over the year. Total construction contract awards in August-October were 34 per cent above year-earlier levels, pointing to a possible increase in construction activity.

Check payments at Memphis banks, which indicate the level of spending, dipped sharply in late 1966 but regained the earlier peak soon after the first of the year. Debits remained relatively high until the autumn months, when they again declined as a result of reduced cotton marketing. Most of the cotton produced in the surrounding area flows through the Memphis market to both domestic and foreign mills. The 1967 crop was down sharply from the 1966 crop, resulting in lower marketings in the area. Department store sales rose 9 per cent, the highest rate among regional metropolitan areas.

Bank deposits, which increased at rates of 2 and 6 per cent, respectively, in 1965 and 1966 , rose 13 per cent last year, reflecting a very expansive national monetary policy. Loans rose sharply early in the year and declined slightly in the autumn months. Investments continued to expand very rapidly.

Ceifton B. Lutrthel Clatre Armenthout 